\title{
Proces adaptacji zapożyczeń językowych - czynniki socjo- i psycholingwistyczne wobec zróżnicowania anglicyzmów w wybranych językach słowiańskich
}

\author{
Mateusz Warchat \\ Univerza v Bielskem-Biali, Fakulteta za humanistiko in družbene vede, Ul. Willova 2, \\ PL-43-309Bielsko-Biała,mawarc@o2.pl
}

\begin{abstract}
SCN II/1 [2009], 85-94
Prilagajanje prevzetih besed se med drugim uresničuje na didaktičnem, glotodidaktičnem in prevajalskem področju. Eden izmed praktičnih rezultatov jezikovne analize je ugotavljanje splošnojezikovnih pravil, načinov in mehanizmov adaptacije. Prispevek poskuša pokazati prevzemanje tujih besed na fonološki, morfološki in semantični ravni, in sicer s pomočjo izbranih angleških izposojenk v slovenskem, hrvaškem, srbskem in bosanskem jeziku.

The process of adapting language borrowings is realized in the following areas: didactic, glotto-didactic and translational, among other areas. A move towards establishing general language parameters concerning rules and the means and mechanisms of such adaptation is one of the practical aspects of the language analysis of borrowings. The objective of the paper is to present the processes of language borrowings, which take place on the following levels: phonological, morphological and semantic. The study has been done on the basis of selected English borrowings that are present in Slovenian, Croatian, Serbian and Bosnian.
\end{abstract}

Ključne besede: prevzete besede, psiholingvistika, sociolingvistika, internacionalizmi, interferenčni procesi, lažni prijatelji

Key words: borrowings, psycholinguistics, sociolinguistics, international words, interferential processes, "lexical trap"

Obecnie analizując poszczególne języki narodowe i ich role w kontekście wzajemnej interferencji i globalnego przenikania języków można odwołać się do stosowanego w lingwistyce pojęcia mocy języka (ang. power of language) 
(por. W. F. Mackey 1976, W. Miodunka 1990, D. Crystal 2003). Przez moc języka rozumie się kilka zjawisk. W kontekście lingwistycznym jest to cecha języka pozwalająca na nazywanie wszelkich przedmiotów i doświadczeń poznawczych, ich porządkowanie i kreowanie na ich podstawie obrazu świata, a więc kategoria kognitywna. W procesie komunikacji jest to cecha języka, dzięki której możliwe jest werbalne oddziaływanie ludzi na siebie. Ta cecha wiąże się z funkcją pragmatyczną języka. W teorii socjolingwistycznej pojęcie mocy języka wiązać należy z kulturowym, ekonomicznym i gospodarczym prestiżem określonej wspólnoty komunikacyjnej, sprawiającym, iż posługujący się jej językiem uzyskują zawodową, społeczną i materialną przewagę nad osobami posługującymi się innymi językami (za: A. Pawłowski 2005). Wśród czynników determinujących tak rozumianą moc języka W. F. Mackey wymienia następujące: liczba mówiących pomnożona przez ich zamożność, dyspersja języka na świecie (im większe rozproszenie języka w świecie, tym większa jego moc), mobilność społeczna nosicieli języka (im większa mobilność nosicieli języka - tym większa jego moc), czynniki ideologiczne (przede wszystkim związki konfesyjne) oraz wartości kulturowe wytworzone przez daną wspólnotę komunikacyjną (zob. W. M. Mackey 1976, 203-214).

Najbardziej widocznym efektem takiej darwinistycznej rywalizacji języków jest intencjonalne lub nieświadome eliminowanie dialektów, niektórych języków etnicznych oraz języków standardowych przez języki międzynarodowe np.: język angielski. Jednym z jej ubocznych skutków jest natomiast reakcja obronna świadomych użytkowników języka polegająca na wspieraniu wielojęzyczności i wielokulturowości.

$\mathrm{Z}$ pojęciem bezpieczeństwa, w tym bezpieczeństwa kulturowo-cywilizacyjnego wiąże się nierozerwalnie kategoria zagrożeń dotyczących również języka. Najważniejsze z nich to: procesy globalizacyjne zachodzące w sferze kultury, konflikty tożsamości narodowych oraz resentymenty nacjonalistyczne i ksenofobie. Na płaszczyźnie kulturowej globalizacja związana jest z natężeniem procesów dyfuzji kulturowej. Zjawisko to bywa różnie określane - od „mimikry kulturowej” przez ,imperializm kulturowy” aż po „macdonaldyzację kulturową" (za: J. Olchowski 2004). Zagrożenia związane z dyfuzją kulturową dotyczą głównie jednostronnego kierunku przepływu wartości kulturowych tj. w obszarze centrum - peryferie. Za sprawą tworzącego się w tej sytuacji konfliktu między poszczególnymi kulturami narodowymi występuje zagrożenie utraty tożsamości narodowej (J. Czaputowicz 1998).

Języki poszczególnych państw byłej Jugosławii w przedstawionym kontekście są nie tylko kategorią historyczno-kulturową, ale przede wszystkim należy jest uznać jako kategorię socjolingwistyczną, etnolingwistyczną i psycholingwistyczną (A. Spagińska-Pruszak 1997). Ten silny zwrot w kierunku badań synchronicznych nad nimi spowodowany jest zmianami makro i mikrojęzykowymi występującymi w tym obszarze. Zmianom wewnątrzjęzykowym i procesowi kodyfikacji nowych języków towarzyszą interferencje nabywane w procesie edukacyjnym, codziennej komunikacji czy zmianie kulturowej, mające często swoje źródło w zapożyczeniach angielskiego pochodzenia wytyczonych 
przez tzw. kulturową ścieżkę globalizacji. Ponadto zagrożenia mają naturę wewnątrzjęzykową i pochodzą od samych użytkowników języka.

Język ciągle ewoluuje, niezależnie od dynamiki zmian pozajęzykowych, zmienia się w czasie, zarówno w idiolekcie użytkownika, jak i jego społecznym wymiarze. Konsekwencją tych zmian jest $\mathrm{m}$. in. tworzenie uzusu językowego. Dużą rolę w tworzeniu uzusu odgrywa opinia i aprobata społeczna, ale na postawy wobec języka wpływa świadomość językowa każdego użytkownika języka. Czynniki psycholingwistyczne determinują między innymi takie postawy wobec języka, które $\mathrm{w}$ znacznym stopniu związane są z powstawaniem nawyków językowych. Użytkownicy, którzy wyznają postawę racjonalistyczną akceptują zmiany w języku oraz twierdzą, że zmiany te są konieczne. Liberaliści akceptują wielostylowość i wielopoziomowość języka. Postawa perfekcjonistyczna wypowiada walkę formom nieprecyzyjnym i wyjątkowym, innowacyjnym oraz dawniejszym. Twierdzi się tu, że język powinien być precyzyjny i zgodny z systemem językowym. Postawa naturalna (zwana też spontaniczną) dotyczy użytkowników odbierających język w sposób naturalny. Zgodnie z postawą logiczną użytkownik twierdzi, iż język powinien być precyzyjny, jednoznaczny i przede wszystkim logiczny. Leseferysta będzie unikał ingerowania w język. Konserwatyści za to pragną odwołania do przeszłości i zachowania form językowych właściwych dla okresu, w którym sami przyswajali język. Najbardziej krzywdzącą postawą wobec języka jest abnegatyzm. Z kolei puryzm egocentryczny przejawia się $\mathrm{w}$ akceptowaniu tylko takich form, jakie użytkownik uważa za poprawne. Puryzm nacjonalistyczny to postawa nie akceptująca obcych form w języku powstałych najczęściej w wyniku zewnątrz i wewnątrzjęzykowych interferencji. Należy podkreślić, że według teorii psychologicznej postawy są rezultatem emocji oraz zachowań. Podobnie stosunek do języka w zakresie zgodności z normą językową lub innowacyjności związany jest $\mathrm{z}$ innymi czynnikami o charakterze psychologicznym: stereotypami, uprzedzeniami czy konfliktami. Przytoczone powyżej przykłady postaw, a szczególnie te, na które składają się komponenty purystyczne odgrywają znaczącą rolę w kształtowaniu relacji rodzimy - obcy wśród wielu narodów południowosłowiańskich.

W badaniach psycholingwistycznych podkreśla się obecność procesów poznawczych: tj. uwagi, pamięci, elementów kategoryzacji i percepcji obecnych w procesie transferu językowego. Podkreśla się również, że warunkiem przeniesienia konstrukcji z jednego języka do drugiego jest jej psycholingwistyczne nacechowanie. Twierdzi się ponadto, że trudności w rozszyfrowaniu danego elementu tj.: ciągu dźwięków, nieokreślonego desygnatu itp., mogą doprowadzić do zakwestionowania poprawności danej konstrukcji (J. Berko Gleason, N. Bernstein Ratner 2005). O transferabilności danego elementu językowego stanowią częstotliwość oraz stopień nacechowania konstrukcji. W teorii psycholingwistycznej nie rozróżnia się również procesów przyswajania i uczenia się języka, wobec czego traktowane są one tożsamo. Można zatem zadać pytanie, czym użytkownik języka będzie kierował się przy wprowadzaniu do własnego leksykonu umysłowego obcego słowa i w jaki sposób określi jego poprawność. 
Kwestia ta dotyczy również różnic i podobieństw między procesami uczenia się oraz przyswajania języka od zapożyczania i adaptacji obcych słów.

W wyjaśnieniu tego zjawiska pomocna jest psycholingwistyczna analiza błędów językowych. Jeden z najczęściej widocznych błędów związany jest z niewłaściwą kategoryzacją i powstaje wskutek niedokładnego odwzorowania (J. Berko Gleason, N. Bernstein Ratner 2005). Dotyczy on przenoszenia błędnego znaczenia całego słowa ze względu na jego dokładne podobieństwo do słowa dostępnego w słowniku użytkownika języka pierwszego. W ten sposób powstają słowa uznane powszechnie za neologizmy lub zapożyczenia ukryte w postaci tzw. kalek językowych.

Być może hipoteza niedokładnego odwzorowania tłumaczy ilość zapożyczeń stanowiących niepoprawne formy językowe, ale realne i prawdopodobne występowanie interferencji mogą wyjaśnić jedynie badania glottodydaktyczne. W tym kontekście ciekawymi byłyby badania podłużne, prowadzone na obszarze południowej słowiańszczyzny, który cechują z jednej strony silna odrębność języków narodowych i szybkie zmiany językowe, a z drugiej strony duża podatność użytkowników na nowe formy zapożyczane.

Jednym z praktycznych przejawów językowej analizy zapożyczeń jest dążenie do ustalenia pewnych prawidłowości dotyczących m.in. ogólnosłowiańskich cech obecnych w procesie adaptacji. Obecnie wyraża się akceptację dla tezy podnoszącej rozwój i obecność procesów zapożyczania na trzech płaszczyznach: fonologicznej, morfologicznej i semantycznej (por. M. Czerwiński 2000). Warstwą, w której wpływy są najbardziej odczuwalne, jest niewątpliwie leksyka (zapożyczenia, internacjonalizmy i/lub wspólne rdzenie słów szczególnie angielskiego pochodzenia). Mówi się także o istnieniu europejskiej ligi językowej (Sprachbund), określanej niekiedy jako SAE (Standard Average European), charakteryzującej się wspólnymi cechami strukturalnymi określanymi jako europeizmy (por. M. Haspelmath,1998 i 2001, A. Majewicz 1989: 170-171).

Z punktu widzenia praktyki glottodydaktycznej ważne jest rozróżnienie pomiędzy internacjonalizmem (tu: anglicyzmem), a aproksymatem, który w procesie akwizycji językowej jest najczęściej efektem błędnej asocjacji. Przyjmuje się, że choć znaczenia internacjonalizmów nie zawszą są identyczne, to znaczenia podstawowe powinny się pokrywać. Gdy intensja, czyli znaczenie W rozumowaniu kognitywnym, w języku docelowym będzie tożsama choć $\mathrm{z}$ jednym znaczeniem języka, z którego użytkownik zapożycza, dany leksem zostanie zaliczony do klasy wyrazów międzynarodowych. Często jednak trudno określić granicę pomiędzy niewielkimi różnicami semantycznymi dzielącymi internacjonalizmy od pseudointernacjonalizmów. J. Volmert przedstawia w tym zakresie koncepcję opartą na dziesięciu tezach definiujących przynależność słowa do grupy internacjonalizmów. Szczególną uwagę zwracają dwie z nich. Pierwsza podkreśla, że wyłącznie funkcja leksemów w aspekcie synchronicznym jest kryterium decydującym o przynależności do interleksemów, a nie ich pokrewieństwo genetyczne. Druga ustala minimalny warunek uznania danego słowa za internacjonalizm tylko wtedy, gdy przynajmniej jeden wspólny semem występuje w danych językach. Wyróżnia się także internacjonalizmy w znacze- 
niu wąskim obecne jako międzynarodowe wyrazy oraz internacjonalizmy w znaczeniu szerokim tj. inne elementy językowe o międzynarodowym zasięgu np.: morfem słowotwórczy -anty (por. J. Maćkiewicz)

Błędy spowodowane aproksymatami najłatwiej zauważyć podczas analizy kontrastywnej par słów tj.: słowa zapożyczonego i jego odpowiednika (tu: słowa pochodzenia angielskiego oraz słów rodzimych w wybranych językach słowiańskich). Wyróżnia się więc kolejno:

- aproksymaty związane z błędnymi kolokacjami - dwukierunkowe, np.: $h r$. elastičan plan - ang. elastic + plan > elastic plan*, słow.fleksibilni plan*; hr. hamburger sa sirom/riblji hamburger* - ang. hamburger; hr. kriminalistički romani - ang. detective romani - hr. detektivski romani*

- aproksymaty o zupełnie odmiennych znaczeniach, np.: ang. affirm - hr. afirmirati se* - ang. asert oneself; ang. eventual - hr. eventualan*

- aproksymaty, w których słowo zapożyczane ma szersze znaczenie od użytego w języku docelowym, np.: hr. profesor - ang. professor

- aproksymaty, w których słowo zapożyczane ma węższe znaczenie lub w ogóle go nie posiada, np.: hr. najlon - ang. nylon; hr. miting - ang. meeting

- aproksymaty obejmujące błędne użycia poprzez niewłaściwe formy sufiksalne i prefiksalne, np.: hr. anorganski - ang. inorganic; hr. anormalan* - ang. anomalous - hr. abnormalan -ang. abnormal; hr. informatika - ang. informatics.

Szczególnie ciekawą grupę stanowią aproksymaty eliptyczne, które najczęściej tworzone są przez formy obojętne źródłowym morfemem. Ta grupa wyraźnie podkreśla ekonomikę poznawczą użytkownika języka np.:

hr. buking - ang. booking (office); hr. koktel - ang. cocktail (party); hr. konzalting - ang. consulting (company, office); hr. dancing - ang. dancing (hall); hr. duty.free - ang. duty free (shop); hr. grejp - ang. grape(fruit); hr. air condition - ang. air condition(ing / er); $h$ r. aerobic - ang. aerobic(s); hr. boks - ang. box(ing); hr. viktimolog - ang. victimolog(ist); hr. pidžama - ang. pyjama(s); hr. traveler ček - ang. traveler's check.

Adaptacja zapożyczeń, szczególnie z języka angielskiego, w językach: słoweńskim, chorwackim, serbskim, czarnogórski czy bośniackim przejawia się tendencjami mającymi często pozajęzykowe źródła. Najbardziej widoczne zapożyczenia obecne w płaszczyźnie leksykalnej korelują z transferem językowym, który wpływa, przede wszystkim, na leksykę danego języka. W zakresie przyczyn wprowadzania pożyczek odróżnia się przyczyny zewnątrzjęzykowe i wewnątrzjęzykowe (E. Mańczak-Wohlfeld 1995: 18). Mówiąc o zewnątrzjęzykowych przyczynach zapożyczania wyrazów należy wspomnieć o konieczności nazywania nowych desygnatów, prestiżu języka (por. wprowadzone wcześniej pojęcie mocy języka) oraz potrzebie utożsamiania się z użytkownikami języka - źródła. Do najważniejszych przyczyn wewnątrzjęzykowych można zaliczyć: - niską frekwencję pewnych wyrazów i konieczność wprowadzania w ich miejsce pożyczek, 
- występowanie par homonimicznych, co prowadzi do zastępowania jednego z homonimów przez obce jednostki leksykalne,

- utratę ekspresywności przez niektóre rodzime wyrazy, co przyczynia się do zapożyczania nowych wyrazów bardziej nacechowanych,

- niekorzystne asocjacje rodzimych leksemów (za: G. A. Kleparski 2001)

Proces zapożyczania ma charakter dynamiczny i polega na przenikaniu, adaptacji oraz rozszerzaniu się nowego elementu aż po zaniknięcie poczucia obcości jednostki leksykalnej (za: G. A. Kleparski 2001). Formy odbierane jako obce mogą być przeniesione bez zmian i wtedy mamy do czynienia z tzw. importacją lub też mogą zostać zastąpione formami rodzimymi, co określa się jako substytucję (por. J. Fisiak 1961). Klasyfikacje zapożyczeń oparte są ponadto na kryteriach: przedmiotu zapożyczenia oraz stopnia pochodzenia. Zapożyczenia właściwe obejmują grupy wyrazów, które przyjmują fonetyczną asymilację. Zapożyczenia strukturalne polegają na zastąpieniu obcego morfemu lub całej obcej struktury rodzimym odpowiednikiem w wyniku czego otrzymuje się wierne tłumaczenie danej konstrukcji obcej. Powstają wtedy tzw. kalki (repliki) wśród których rozróżnia się kalki słowotwórcze, kalki frazeologiczne oraz kalki znaczeniowe. Kolejną grupę stanowią zapożyczenia semantyczne polegające na rozszerzaniu znaczenia wyrazów rodzimych, gdy do istniejącej już w systemie leksykalnym konstrukcji zapożyczane jest nowe znaczenie. Ciekawe formy tworzone są przez zapożyczenia sztuczne z pierwiastków obcych zgodnie z zasadami języka zapożyczającego. Wyrazy powstałe tym sposobem tzw. hybrydy oparte są na elementach pochodzących tylko z jednego języka lub z różnych języków.

W poszczególnych językach narodów byłej Jugosławii obserwuje się zarówno podobne jak i odmienne formy adaptacji zapożyczeń angielskich.

W języku serbskim obserwuje się zapożyczenia bezpośrednie z języka angielskiego np.: monitoring oraz wyrazy adaptowane pod wypływem internacjonalizmów za pomocą morfemów słowotwórczych np.: edukacija, evaluacija. Te wyrazy są z czasem włączane w system językowy, a konkretnie podsystem semantyczny języka serbskiego (T. Prćić 2004). Formy graficzna niektórych zapożyczeń często odwzorowuje formę źródłową, np.: e-mail, air bag. Pojawiają się też formy łączone, np.: online šoping oraz hybrydowe, np.: brend konferencja, spa centar, wireless mreža. Drugą grupę zapożyczeń stanowią elementy leksykalne oraz syntaktyczne, które ,zanurzone są” w pewnych formach językowych np.: kopija knjige. Powstają w ten sposób ukryte zapożyczenia językowe tzw. kalki językowe. Codzienna praktyka językowa (widoczna m.in. w języku środków masowego przekazu) dostarcza wielu przykładów użycia anglojęzycznych odpowiedników rodzimych wyrazów, np.: pozorište - teatar, činjenjica - fakat itp. Frekwencja używania form obocznych zależy w głównej mierze od czynników pozajęzykowych np.: mody językowej.

Synonimiczne relacje pomiędzy anglicyzmami a zadomowionymi lub niezadomowionymi ich formami występującymi w języku serbskim można podzielić na trzy grupy. Pierwsza obejmuje anglicyzmy zachowane w formie oryginalnej, 
które w praktyce językowej wypierają formy rodzime, np.: menedžment - poslovodstvo, uprava; start - početak. Druga grupa obejmuje anglicyzmy, które adaptowane są na płaszczyźnie fonologicznej, np.: imejl - elektronska pošta, bičvolej - odbojka na pesku. Źródłem fonologicznej adaptacji tych wyrazów jest ekonomia językowa widoczna w wyrażaniu w rodzimym języku słów, które wymagałyby dłuższego tłumaczenia poprzez opis. Trzecia grupa obejmuje wyrazy obecne w języku, który zapożycza (tu: serbskim), przyjmujące znaczenia hiponimiczne, np.: kompjutor - laptop.

Analiza obserwowanych w praktyce językowej tendencji do wypierania form rodzimych przez formy zapożyczone wskazuje na kilka przyczyn. Tkwią one często w źródłach o charakterze psycholingwistycznym i socjolingwistycznym. Z grupy synonimów użytkownik języka wybiera najczęściej formy, które są nowe, „lepiej” brzmiące, krótsze oraz modniejsze. Podświadomie wypierane są również formy postrzegane jako archaiczne, np.: akt - čin, finalan - krajni. Efektem zapożyczeń językowych jest również pojawianie się pleonazmów, np.: fastfood hrana, widescreen ekran.

W języku chorwackim w zakresie zapożyczeń na płaszczyźnie fonologicznej obserwuje się tendencje do zachowania form oryginalnych (szczególnie w pisowni), np.: coming out. Pojawiają się często związki syntagmatyczne w formie hybrydowej takie jak.: break lopta, hip-hop kultura, street odjeća, web poduzetnik, e-djevojka, on-line naručivanje Bardzo często pożyczki widoczne są w klasie wyrazów obejmujących nazwy zawodów np.: broker, menadżer. Język chorwacki, w odróżnieniu od języka serbskiego, wprowadza tu jednak paralelny dla podobnej klasy wyrazów zakorzenionych w języku sufiks $-a \check{c}$, przy pomocy którego tworzone są nazwy niektórych zawodów, np.: boksač, tenisač. Rzeczowniki rodzaju żeńskiego podczas adaptacji form angielskich otrzymują w języku chorwackim końcówkę -ica. W odróżnieniu od języka chorwackiego w języku serbskim obserwujemy tworzenie rzeczowników rodzaju żeńskiego poprzez morfemy -ka, -kinja.

Adaptacja morfologiczna obejmuje także w języku chorwackim grupy czasowników pochodzenia angielskiego np.: šoping, holding, trening. Zarówno w języku chorwackim, jak i serbskim, można zaobserwować tendencje słowotwórcze motywowane komunikacyjnymi potrzebami ich użytkowników. W ten sposób powstają nowe słowa np.: head - hunterica, frendica oraz blogerka. Podobnie wtórna adaptacja występuje przy tworzeniu form deminutywnych, np.: pornić. Procesy słowotwórcze obejmują również grupę przymiotników, które w języku serbskim i chorwackim derywowane są od podstaw angielskiego pochodzenia np.: marketing - marketinški, softver - sovtferski, partner-partnerski.

Semantyczna adaptacja we wspomnianych językach odbywa się poprzez wprowadzenie słów pochodzenia angielskiego i używanie ich w innych funkcjach niż pierwotnie występowały w języku, z którego zostały zapożyczone. W ten sposób w zdaniach pojawiają się rzeczowniki, które spełniają funkcję przymiotnika, np.: odpjevati ,, best off”, beba ,,on board". Proces ten widoczny jest szczególnie w polach semantycznych słów związanych z ekonomią, filmem, muzyką, modą, polityką czy informatyką. 
Zmiany pojawiające się w korpusie leksykalnym wspomnianych języków za sprawą procesów adaptacyjnych, szczególnie o charakterze semantycznym, wpływają zarówno na uproszczenia, jak i rozszerzenia znaczeń słów zapożyczanych. W aspekcie psycholingwistycznym symplifikacja znaczenia spowodowana jest potrzebą użytkownika języka rodzimego do określania rzeczywistości pozajęzykowej w sposób jednoznaczny, w konkretnym użyciu i kontekście. Rozszerzenie znaczenia jest natomiast procesem, który cechują silne i błędne asocjacje, będące źródłem interferencji występujących zarówno wewnątrz języka, jak i na zewnątrz języka. Procesy interferencyjne widoczne są szczególnie w obrębie akwizycji języka, kiedy użytkownik tworząc wypowiedzi transformuje słowo z własnego języka (L1), obecne w nim jako anglicyzm, na język drugi (L2) lub dokonuje transformacji w obrębie samego języka (L2). Przykładem może być w obu wspomnianych językach morfologiczna adaptacja czasowników przy pomocy sufiksów -ati, -irati, -ovati, np.: kidnapirati, blefirati, skenirati (w języku chorwackim) czy bukirati, boksovati, dizajnirati (w języku serbskim). W procesie akwizycji na poziomie tworzenia czasowników może dochodzić do powstawania form niepoprawnych poprzez nadgeneralizację sufiksów. Błędy wynikające $z$ interlingwalnych oraz intralingwalnych różnic semantycznych są niebezpiecznie szczególnie w źle zaplanowanym programie glottodydaktycznym. Powstawanie replik spowodowanych utwierdzonymi błędnymi nawykami może prowadzić do utrudnień w komunikacji, szczególnie, gdy wyraz ma inne znaczenie w źródłowym i docelowym języku lub znaczenia pokrywają się tylko częściowo.

W procesie standaryzacyjnym języka czarnogórskiego obserwuje się również wpływy języka angielskiego oraz angloamerykańskiej kultury, szczególnie na leksykę tego języka. Silnie zaznacza się w badaniach nad aglicyzmami występującymi w języku czarnogórskim kryterium celowości zapożyczania słów, które w języku mają swoje rdzenne odpowiedniki, np.: stejdž - scena, pozornica; ofis - kancelarija. Podobnie jak w językach chorwackim i serbskim część wyrazów źródłowych jest symplifikowana poprzez używanie replik tylko w jednym znaczeniu np.: oficir - w odniesieniu wyłącznie do stopnia oficerskiego.

Po ogłoszeniu niepodległości i decyzji uznającej język bośniacki za równoprawny, zaistniała konieczność wprowadzenia oficjalnej terminologii w tym języku. Nowe wzory i nowe nazwy przechodzą obecnie proces ciągłego utrwalania się, a wielokrotnie użytkownicy języka wahają się przy wyborze odpowiedniego leksemu w języku bośniackim (A. Hofman-Pianka 2000). Najwięcej wpływów języka angielskiego obserwuje się w terminologii politycznej, której adaptację w znacznym stopniu utrwalają środki masowego przekazu. W tłumaczeniu Porozumienia Pokojowego z Dayton znajdujemy następujące zapożyczenia, co ciekawe, kontrastujące z rodzimymi formami ich chorwackich odpowiedników:

Por:

(bos.) centralni registar

(bos.) front

(bos.) implementacija

(hr.) središnji registar

(hr.) bojište

(hr.) provedba 
(bos.) komandant

(bos.) ofanzivna operacija

(bos.) rezerve (hr.) zapovjednik

(hr.) napadačka djelovanja

(hr.) pričuve

Wydaje się, że w kontekście analizy psycho- i socjolingwistycznych mechanizmów adaptacji internacjonalizmów (szczególnie anglicyzmów) potrzebne byłyby podłużne badania w grupie języków podobnych (tu. słowiańskich). Rezultaty bowiem mogły by się znacznie przyczynić do usprawnienia metodyki nauczania języków i tym samym unikania powstawania błędnych nawyków językowych. Ponadto analiza procesów interferencyjnych w obszarze południowej słowiańszczyzny jest szczególnie istotna w dobie zarówno tendencji globalistycznych jak i separatystycznych, które cechują ten obszar językowy.

\section{WYKAZ SKRÓTÓW}

hr. - leksem chorwacki; serb. - leksem serbski; bos. - leksem bośniacki; słow. leksem słoweński; * - forma niepoprawna

\section{BIBLIOGRAFIA}

J. BERKO GLEASON, N. BERNSTEIN RATNER (red.), 2005: Psycholingwistyka. Gdańsk: Gdańskie Wydawnictwo Psychologiczne.

D. CRYSTAL, 2003: English as a Global Language. Cambridge: Cambridge University Press.

J. CZAPUTOWICZ, 1998: System czy nieład? Bezpieczeństwo europejskie u progu XXI wieku. Warszawa: PWN.

M. CZERWIŃSKI, 2000: Usporedba adaptacije nekih anglicizama u hrvatskom i poljskom jeziku. Fluminensia, br 1-2.

J. FISIAK, 1961: Zapożyczenia angielskie w języku polskim. Analiza interferencji leksykalnej. Rozprawa doktorska.

M. HASPELMATH, 1998: How young is Standard Average European? Language Sciences 20, 271-287.

A. HOFMAN-PIANKA, 2000: Socjolingwistyczne aspekty wspótczesnego języka bośniackiego. Kraków: Wydawnictwo Radamsa.

G. A. KLEPARSKI, 2001: Angielskie zapożyczenia leksykalne w języku polskim i niektóre problemy ich adaptacji. Zeszyty naukowe Wyższej Szkoły Pedagogicznej w Rzeszowie 42.

W. F. MACKEY, 1976: Bilinguisme et contact des langues. Paris: Klincsieck. 
J. MAĆKIEWICZ, 2001: Wyrazy międzynarodowe (internacjonalizmy) we współczesnym języku polskim. Współczesny język polski. Red. J. Bartminski. Lublin.

A. F. MAJEWICZ, 1989: Języki świata i ich klasyfikowanie. Warszawa: PWN.

E. MAŃCZAK-WOHLFELD, 1994: Angielskie elementy leksykalne w języku polskim. Kraków: Wydawnictwo Platan.

- -, 1995: Tendencje rozwojowe współczesnych zapożyczeń angielskich $w$ języku polskim. Kraków.

W. MIODUNKA, 1990: Moc języka i jej znaczenie w kontaktach językowych i kulturowych. Język polski w świecie. Red. W. Miodunka. Warszawa: PWN. 39-49.

A. PAWŁOWSKI, 2004: Język w konstytucjach wybranych państw europejskich. Poradnik Językowy 4/613, 10-25.

--, 2005: Język polski w Unii Europejskiej: szanse i zagrożenia. Poradnik Językowy 10, 3-27.

T. PRĆIĆ, 2004: O anglicizmima iz četiri različita ali međupovezana ugla. Zbornik Matice Srpske za folologiju i lingwistiku, XLVII/1-2. Novi Sad.

A. SPAGIŃSKA-PRUSZAK, 1997: Sytuacja językowa w byłej Jugosławii. Gdańsk: Wydawnictwo Uniwersytetu Gdańskiego.

\section{PRILAGAJANJE PREVZETIH BESED - SOCIO- IN PSIHOLINGVISTIČNI DEJAVNIKI RAZLIČENJA ANGLICIZMOV V IZBRANIH SLOVANSKIH JEZIKIH}

Avtor predstavlja sociolingvistične in psiholingvistične kriterije, ki odločajo o »sprejemljivosti« novih jezikovnih oblik. Internacionalizmi so pomemben problem za raziskovalce in uporabnike jezika, ker se kot posledica interferenčnih procesov veliko hitreje pojavijo v idiolektu kot v knjižnem jeziku. Zaradi njihove narave metodologija opisovanja zahteva uporabo sinhronih kriterijev. Analiza v jezikovni praksi prisotnih tendenc po nadomeščanju domačih oblik s prevzetimi kaže na zunajjezikovne razloge. Predstavljene so tudi hipoteze $\mathrm{v}$ zvezi z vlogo jezikovnega prenosa kot posledica napačnih asociacij prevzetih besed $\mathrm{v}$ besedotvornih procesih. Cilj prispevka je $\mathrm{v}$ didaktičnem kontekstu usmeriti pozornost na pomen primerjalnih raziskav prevzetih besed $\mathrm{v}$ slovanskih jezikovnih sistemih. 